\title{
Article \\ Environmental Benefit of Alternative Binders in Construction Industry: Life Cycle Assessment
}

\author{
Girts Bumanis (D), Aleksandrs Korjakins *(D) and Diana Bajare (D)
}

Citation: Bumanis, G.; Korjakins, A.; Bajare, D. Environmental Benefit of Alternative Binders in Construction Industry: Life Cycle Assessment. Environments 2022, 9, 6. https:// doi.org/10.3390/environments9010006

Academic Editors: Claudio Ferone and Yu-Pin Lin

Received: 15 November 2021 Accepted: 30 December 2021 Published: 4 January 2022

Publisher's Note: MDPI stays neutral with regard to jurisdictional claims in published maps and institutional affiliations.

Copyright: (C) 2022 by the authors. Licensee MDPI, Basel, Switzerland. This article is an open access article distributed under the terms and conditions of the Creative Commons Attribution (CC BY) license (https:// creativecommons.org/licenses/by/ $4.0 /)$.

\author{
Department of Building Materials and Products, Institute of Materials and Structures, Riga Technical University, \\ LV-1658 Riga, Latvia; girts.bumanis@rtu.lv (G.B.); diana.bajare@rtu.lv (D.B.) \\ * Correspondence: aleksandrs.korjakins@rtu.lv
}

\begin{abstract}
Carbon dioxide $\left(\mathrm{CO}_{2}\right)$ emissions associated with Portland cement (PC) production is ranked as the highest among the construction materials and it is estimated that $8 \%$ of the worlds $\mathrm{CO}_{2}$ discharges is due to PC production. As an average, the production of PC clinker including calcination process generates $0.81 \mathrm{~kg}$ of carbon dioxide per one $\mathrm{kg}$ of cement. Hence, new approaches which limit the negative environmental impacts of cement production and are aimed at the development of advanced methodologies are introduced. Implementation of lower energy consumption materials in production, which could moderately substitute PC in binders, can be addressed as one of the probable methods in mitigating environmental risks. Therefore, alternative binders fit into the most promising solutions. Present research investigates the environmental impact of the building sector, if an alternative to PC binder is used. Life cycle assessment (LCA) was used in this research to assess the environmental impact of the alternative ternary gypsum-PC-pozzolan binder in the production of mortar, and the environmental benefits were calculated and compared to traditional cement-based building materials. Phosphogypsum was considered as a secondary raw material, as in the current approach it is collected in open stacks bringing environmental concerns. SimaPro LCA software with the Ecoinvent database was used for most of the calculation processes. Results indicate that with alternative binders up to $30 \%$ of energy can be saved and $57 \mathrm{wt} . \%$ of $\mathrm{CO}_{2}$ emissions can be reduced, bringing positive impact on the construction industries contribution to the environment.
\end{abstract}

Keywords: life cycle assessment; construction industry; emissions; substitution; ternary binder; gypsum; phosphogypsum; pozzolan; Portland cement

\section{Introduction}

According to the data of the International Energy Agency (IEA, 2019), 7\% of the worlds $\mathrm{CO}_{2}$ discharges are caused due to cement production, and it is ranked as the maximum contributor among construction materials [1,2]. As an average, the pre-heating of PC and calcination process generate $0.81 \mathrm{~kg}$ of $\mathrm{CO}_{2}$ per $1 \mathrm{~kg}$ of cement. In addition, other harmful environmental effects can lead to dangerous human health risks [3]. Some investigations revealed that there can be risks of cancer for the people interacting in industrial factories, such as cement production and lime production [4]. Serious risk factors related to cement use (hexavalent chromium, exposure to allergens, or free crystalline silica) can result in harmful health consequences to humans [5]. Hence, new approaches that limit the negative environmental impacts of cement production and are aimed at the development of advanced methodologies were introduced [6,7]. Implementation of lower energy consumption materials in production, which could moderately substitute PC in binders, can be addressed as one of the probable methods in mitigating environmental risks [8]. Previously, various kinds of supplementary cementitious materials were used to replace PC from 5 to $40 \mathrm{wt}$ \% with different efficiency [9,10]. Another approach is to develop and use an entirely different type of binder. As such, calcined gypsum and cement hybrid systems can fit in to the most appealing solutions. 
The production of cement consists of many stages, but the most energy consuming and distinctive stage from other mineral binder productions is associated with heat treatment, of up to $1400{ }^{\circ} \mathrm{C}$ [11]. The emissions of air pollutants released in the cement manufacturing is mainly due to the decarbonation of limestone in clinker production (which releases roughly $0.53 \mathrm{t}$ of $\mathrm{CO}_{2}$ per ton of clinker) as well as the burning of fuels for heat energy. The carbon dioxide $\left(\mathrm{CO}_{2}\right)$, nitrogen oxide $\left(\mathrm{NO}_{\mathrm{x}}\right), \mathrm{SO}_{2}, \mathrm{CO}, \mathrm{PM}_{2.5}$, and $\mathrm{PM}_{10}$ emissions are the major air emissions. The LCA has been performed, not only for PC alone, but it is also calculated as a binder in more complex composites [12,13]. There are reports where the LCA of the cement binders' materials has been done previously by comparing different traditional mortar mixes. Previously, investigations concluded that historical hydraulic mortar with calcined kaolin addition showed similar results as pure lime mortar, while they had by around $22 \%$ lower $\mathrm{CO}_{2}$ release [11]. Blended cements often are referred to as one of the solutions for environmental footprint reduction in the cement industry. Pozzolans and industrial by-products are widely used in cement production. Furthermore, the use of pozzolans sound promising for the reduction of environmental impact during cement use in construction industry, as pozzolans often are subjected to heat treatment, which contributes to $\mathrm{CO}_{2}$ release.

Metakaolin (MKW) $\left(\mathrm{Al}_{2} \mathrm{Si}_{2} \mathrm{O}_{7}\right)$ is a high dynamic aluminosilicate compound, most often known as calcined clay, and is created by de-hydroxylation of kaolin clays $\left(\mathrm{Al}_{2}(\mathrm{OH})_{4} \mathrm{Si}_{2} \mathrm{O}_{5}\right)$ with a heating temperature in the range from 700 to $800{ }^{\circ} \mathrm{C}$ [14]. Besides heating, $\mathrm{MKW}$ production consists of the mining of kaolin, refining, de-watering, and drying. Production of $\mathrm{MKW}$ is associated with the release of dust, $\mathrm{CO}_{2}$, vapor to air and to land, water mineral waste, and discharged mixed mineral water. Furthermore, the main environmental impact factor is due to gas emission for MKW, and it is calculated as $40.1 \%$ for 1 ton. This value is relatively less than the PC impact on environment by air pollution (which is made by both $\mathrm{CO}_{2}$ and acidification) [11]. Moreover, studies show that additional factors, such as ozone layer depletion, human toxicity, fresh water aquatic toxicity, and photochemical oxidation other than $\mathrm{CO}_{2}$ emission, which are associated with environmental effects of numerous levels, are considerably higher than PC [15]. Comparison of PC, MKW, and sand environmental impact has been summarized in previous research [16]. Production of PC has a high impact on abiotic depletion, global warming potential, ozone layer depletion, human toxicity, freshwater aquatic ecotoxicity, and others, while MKW has a high impact on marine aquatic ecotoxicity. Environmental impact of sand is the lowest when compared to cement and MKW as it does not require high energy input in the form of heat. The large amount of sand excavation and consumption leads to high environmental impact on marine aquatic ecotoxicity.

Natural gypsum ore (raw or crude gypsum) is a relatively soft, rock-like mineral with a chemical formula of $\mathrm{CaSO}_{4} \times 2 \mathrm{H}_{2} \mathrm{O}$ (calcium sulfate dihydrate). Gypsum rock is open pit quarried or mined underground, generally by drilling and blasting, then moved to a primary crusher on the quarry/mine site. The quarry process is similar for other mineral materials. Gypsum binder is manufactured by heating fine gypsum, and it is partially dehydrated to calcium sulfate hemihydrate [17]. There are several artificial gypsum byproducts which could be use in substitution of natural gypsum. Not many findings have been carried out to analyze the environmental impacts of using recycled gypsum, while it is known that up to $65 \%$ of energy reduction can be achieved by use of artificial gypsum $[18,19]$. Heating at $150{ }^{\circ} \mathrm{C}$ is used to produce gypsum binder, even though research demonstrates information from databases on this process was conducted with the absence of primary date $[20,21]$. Normalized endpoint results indicate that by substituting natural gypsum with recycled gypsum, production impact can be reduced from 17 to 7 points. The main impact is on saving natural resources, which is the logical conclusion, as processing of secondary gypsum requires similar treatment steps as for natural gypsum (crushing, grinding, burning) [22]. One such alternative gypsum source is phosphogypsum (PG), which is the calcium sulphate co-product of the phosphate fertilizer industry. Previously, it was associated as 'toxic waste' or 'radioactive waste' and labelled PG as not welcome 
in commercial use, limited such waste management and disposal [23]. The radioactivity level of the PG mostly depends on its origin. PG radionuclide activity concentration index I typically varies between 0.7 and 2, and in the European Commission the recommended radioactivity limit is $\mathrm{I} \leq 1.0$ to identify whether a building material is radiologically safe. PG exhibited the ${ }^{226} \mathrm{Ra}$ content of $50.9 \mathrm{~Bq} / \mathrm{kg}$, with an activity concentration index I = 0.51, which is well below the limit value according to regulations [24]. If left unchallenged, PG would continue to be stacked on land in the billions of tons or discharged to the seas. Disposal of PG waste in stacks, which is currently the most common management method, is ranked as the least preferred from environmental point of view. As an example, using Ecoindicator 99 and the egalitarian perspective, total scores were 12.807, $-5.334,-0.064$, and 15.484 points $(\mathrm{Pt})$ for brick production, soil amendment, road construction and stack disposal, respectively. Among indicative impact categories, carcinogen scores were 7.643, $-0.228,0.0001$, and $0 \mathrm{Pt}$, respectively. Respiratory inorganics scores were $-0.192,-4.540$, -0.0383 , and $0 \mathrm{Pt}$, respectively. Gypsum as binder gives low mechanical performance material and the most critical aspect is its elasticity and low water tightness. In such a way it is not comparable to PC binder. New and perspective gypsum-based binder is associated with a ternary system binder called gypsum-PC-pozzolan (GCP). With gypsum content up to $50 \%$, similar performance as seen for PC can be reached [25].

Current affairs urge the need for a solution necessary for reduction of environmental impact of PC and the efficient disposal of artificial materials, which often is associated as waste and by-products. Our current investigation evaluates alternative cement mortar material based on a ternary system binder composed of GCP, and its environmental impact is compared to the traditional cement mortar, as well as cement mortar with partial cement replacement with pozzolan.

\section{Materials and Methods}

This study includes information about the production phase of mortar widely used in civil engineering. The LCA was calculated by using the LCA program SimaPro 8 software. The ISO 14044 standards (ISO, 2006a, ISO, 2006b) and the ILCD handbook guidelines (EC, 2010, 2011) were followed. In this research the CML-IA baseline, cumulative energy demand method, and ecosystem damage potential methods were used to assess the mortar's impact on the ecosystem [18]. In this research the LCA tool was used to examine alternative PC based mortars in the LCA stage "cradle-to-gate", including an assessment for each of its components in order to provide possibilities for developing high performance mortar with less impact on environments. The results of the analysis are presented in the form of bar diagrams and tables, in which the positive sign indicates environmental burden and the negative sign indicates environmental benefit, with respect to energy and materials involved in the study.

The system boundaries separate the system being studied from the ecosphere and the rest of technosphere. Therefore, energy and material flow in and out of these boundaries must be included in the life cycle inventory. In defining system boundaries, three components were considered: (1) capital goods, (2) collection and transportation of PG and other materials, and (3) the transport and treatment of secondary products and final residuals [26]. The boundaries of the analysis begin with PG withdrawal from the stack and the application of the alternative management methods. Production of PG during production of phosphoric acid was not considered. It was assumed that PG withdrawal did not occur during rain periods and the moisture of the stack did not exceed $10 \%$. Moisture is needed to assess PG dry mass and emission. Capital goods (e.g., buildings, materials) were excluded, since it was considered that they were the same for both: the conventional materials and PG waste.

The factory which would produce proposed material are assumed to be located in Kedainiai-2 km from the source of artificial gypsum source-PG stock in AB Lifosa plant (Figure 1). The PC from the cement plant were proposed as a second component located $160 \mathrm{~km}$ from the production site. Metakaolin containing waste (MKW) was produced at 
a distance of $180 \mathrm{~km}$. Transport in a truck 10-20 t, EURO5, 80\%LF, empty return/GLO Economic was assumed.

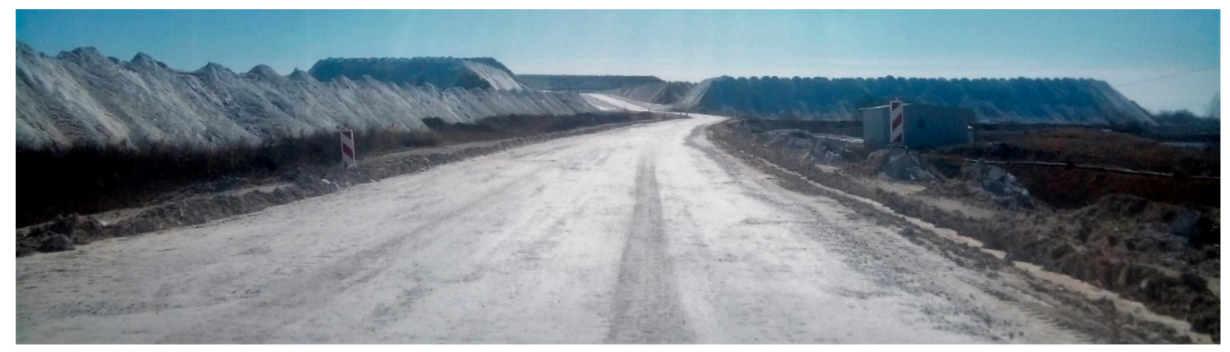

Figure 1. Stacks of phosphogypsum at a fertilizer production plant in AB Lifosa, Kedainiai, Lithuania.

The functional unit of LCA is the production of $1 \mathrm{~m}^{3}$ of mortar, which is expressed as the composition of raw materials. The majority of LCA studies on solid waste management are used a functional unit of $1 \mathrm{t}$ or $1 \mathrm{~m}^{3}$ of waste [26,27]. From a context point of view, this study is classified as a C1 case, according to the ILCD guidelines [28]. As such, attributional LCA with average data is used [26,29]. The declared unit is defined as the quantity of a construction product for use as a reference unit in an EPD, based on LCA for the expression of environmental information in information modules.

Mixture compositions of $1 \mathrm{~m}^{3}$ of mortar are given in Table 1 . Four mortar mixture compositions were compared. Traditional cement mortar with 100\% CEM (PC) was used as reference. Next, mortar with waste metakaolin (MKW) as supplementary cementitious material (25 wt.\% from PC) was used. Ternary system binder based on gypsum-cementpozzolan (GCP) was elaborated in a previous study, and was used in LCA as an alternative binder [25]. Mortar with a binder-to-sand ratio of 1:2 was prepared. Superplasticizer was added as a chemical admixture to reduce the water-binder ratio, and it was adjusted for each composition to obtain a similar workability for better comparison of mortars. Both commercial gypsum (BG) and PG were used as binders' components in the calculations. The properties of mortars were comparable as compressive strength for all mortars, after 28 days of curing were above $50 \mathrm{MPa}$ at dry state curing and $80 \mathrm{MPa}$ at moist condition curing. All three types of mortar were comparable depending from technological and mechanical performance. Such mortar with high PC concentration and strength is often used in repair works and as filament in important steel or reinforced concrete design elements.

Table 1. Mixture compositions for $1 \mathrm{~m}^{3}$ of mortar with different types of binder, $\mathrm{kg} / \mathrm{m}^{3}$.

\begin{tabular}{ccccc}
\hline Component & $\mathbf{1 0 0} \%$ CEM & CEM with MKW & GCP with PG & GCP with BG \\
\hline PG & - & - & 370 & 0 \\
BG & - & 0 & 0 & 370 \\
CEM I & 670 & 520 & 150 & 150 \\
MKW & - & 150 & 150 & 150 \\
SP & 5 & 8 & 10 & 10 \\
Water & 230 & 230 & 230 & 230 \\
Sand & 1340 & 1340 & 1340 & 1340 \\
\hline Density, $\mathrm{kg} / \mathrm{m}^{3}$ & 2245 & 2248 & 2250 & 2250 \\
\hline
\end{tabular}

Natural minerals can be preserved by the replacement of natural gypsum with PG. To produce $1 \mathrm{t}$ of gypsum binder about $1.2 \mathrm{t}$ of natural gypsum must be excavated, transferred, and treated. Next, the binder must be delivered to the production site. If the production site is located near stocks of PG, the delivery distance is much shorter and the utilization of PG in stocks is avoided (Figure 2). For environmental safety, such approach seems logical and must be supported. 


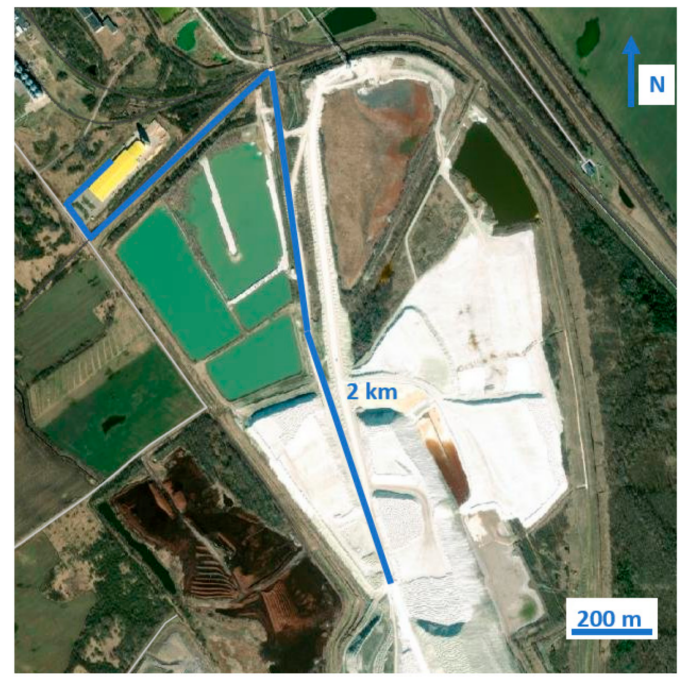

Figure 2. The proposed location of a production site near PG stocks.

Figure 3 represents the input parameters for LCA calculation for all four mortar mixtures. All mortar components and their transportation are included in the material description. The mixing process of mortars are included in calculations. Allocation of MKW was assumed, as MKW is a by-product from a foam glass granule production plant. A total of $20 \%$ was allocated to MKW as by-product, and $80 \%$ of total input was allocated to foam glass granule production as it is the main process of why heat is produced, and kaolin clay is used to avoid conglomeration of foam glass granules. Metakaolin is a high value product if it is produced by purpose; up to $2.5 \mathrm{GJ} / \mathrm{t}$ of energy must be produced and a similar amount is needed to produce PC clinker (3.6-6 GJ) [30]. If no allocation would be used, the environmental impact would be in higher scale.

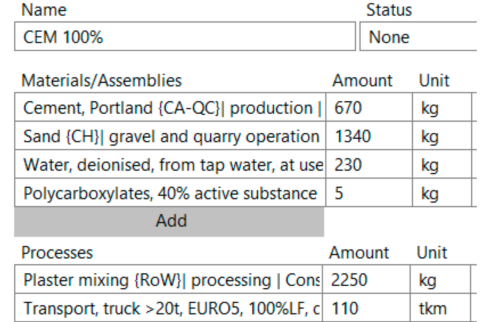

(a)

\begin{tabular}{|c|c|c|}
\hline Name & \multicolumn{2}{|c|}{ Status } \\
\hline CEM $25 \%$, MKW $25 \%$ BG 50\% & None & \\
\hline Materials/Assemblies & Amount & Unit \\
\hline Cement, Portland $\{C A-Q C\} \mid$ production | & 150 & $\mathrm{~kg}$ \\
\hline Sand $\{C H\} \mid$ gravel and quarry operation & 1340 & $\mathrm{~kg}$ \\
\hline Water, deionised, from tap water, at use & 230 & $\mathrm{~kg}$ \\
\hline Polycarboxylates, $40 \%$ active substance & 10 & $\mathrm{~kg}$ \\
\hline metakaolin, $1 \mathrm{~kg}$ & 150 & $\mathrm{~kg}$ \\
\hline Gypsum plaster, 1kg & 370 & $\mathrm{~kg}$ \\
\hline \multicolumn{3}{|l|}{ Add } \\
\hline Processes & Amount & Unit \\
\hline Plaster mixing \{RoW\}| processing | Cons & 2250 & $\mathrm{~kg}$ \\
\hline Transport, truck >20t, EURO5, 100\%LF, c & 110 & $\mathrm{tkm}$ \\
\hline Transport, truck > 20t, EURO5, 100\%LF, c & 26 & $\mathrm{tkm}$ \\
\hline
\end{tabular}

(c)

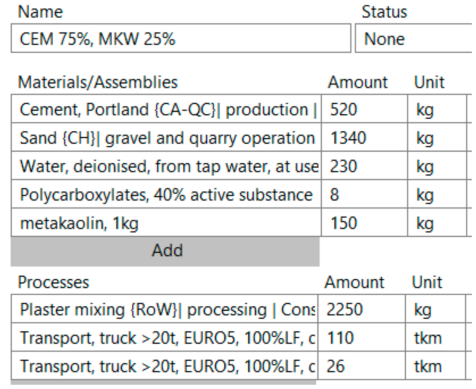

(b)

\begin{tabular}{|c|c|c|}
\hline Name & \multicolumn{2}{|c|}{ Status } \\
\hline CEM $25 \%$, MKW $25 \%$ PG 50\% & \multicolumn{2}{|c|}{ None } \\
\hline Materials/Assemblies & Amount & Unit \\
\hline Cement, Portland $\{C A-Q C\} \mid$ production | & 150 & $\mathrm{~kg}$ \\
\hline Sand $\{\mathrm{CH}\} \mid$ gravel and quarry operation & 1340 & $\mathrm{~kg}$ \\
\hline Water, deionised, from tap water, at use & 230 & $\mathrm{~kg}$ \\
\hline Polycarboxylates, $40 \%$ active substance & 10 & $\mathrm{~kg}$ \\
\hline metakaolin, $1 \mathrm{~kg}$ & 150 & $\mathrm{~kg}$ \\
\hline Phosphogypsum, 1kg & 370 & $\mathrm{~kg}$ \\
\hline \multicolumn{3}{|l|}{ Add } \\
\hline Processes & Amount & Unit \\
\hline Plaster mixing $\{$ RoW $\} \mid$ processing | Cons & 2250 & $\mathrm{~kg}$ \\
\hline Transport, truck > 20t, EURO5, 100\%LF, c & 26 & tkm \\
\hline Transport, truck > 20t, EURO5, 100\%LF, c & 26 & $\mathrm{tkm}$ \\
\hline
\end{tabular}

(d)

Figure 3. Input data in SimaPro software for $1 \mathrm{~m}^{3}$ of mortar $\left(2250 \mathrm{~kg} / \mathrm{m}^{3}\right)$. (a) Cement mortar with 100\% CEM; (b) cement mortar with MKW; (c) GCP mortar with commercial gypsum; (d) GCP mortar with PG. 


\section{Results}

Total energy demand depending on the fuel source, according to the cumulative energy demand, as displayed in Figure 4. The mortar made with cement has the highest total energy demand-4.2 GJ. The partial cement replacement with MKW reduced the total energy demand to $4.0 \mathrm{GJ}$, which was associated with a lower energy demand needed to produce MKW. Mortar made with GCP binder had the lowest energy demand. GCP made of commercial gypsum had a total energy demand of 3.4 GJ. Further total energy demand reduction was for GCP with PG. It was calculated that $2.9 \mathrm{GJ}$ of energy was needed.

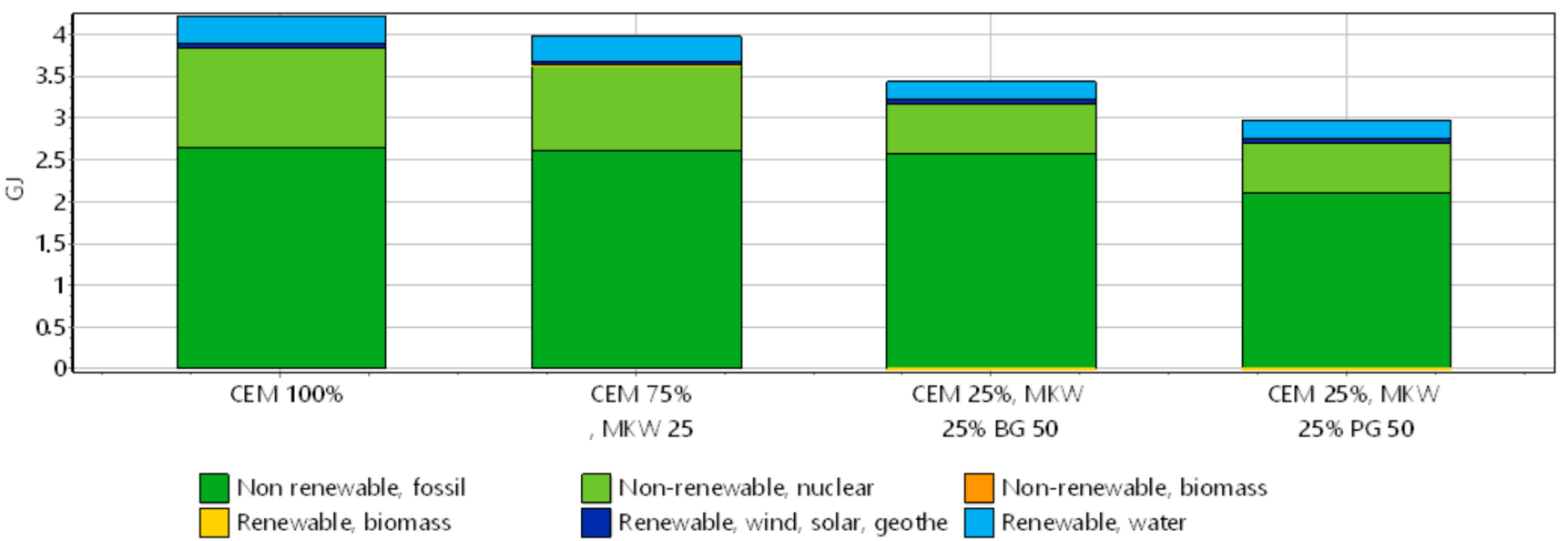

Figure 4. Total energy demand to produce $1 \mathrm{~m}^{3}$ of mortar.

The total $\mathrm{CO}_{2}$ released according to greenhouse gas protocol was 1.02; calculations are given in Table 2. A total of $684.6 \mathrm{~kg}$ of $\mathrm{CO}_{2}$ was released to produce $1 \mathrm{~m}^{3}$ of mortar with $100 \% \mathrm{CEM} . \mathrm{CO}_{2}$ release reduction was achieved with the incorporation of supplementary cementitious material MKW. GCP binder $\mathrm{CO}_{2}$ released during production was reduced to $332.2 \mathrm{~kg}$ for GCP with commercial gypsum, and to $297.0 \mathrm{~kg}$ for GCP with PG. Calculation data according to Ecosystem Damage Potential V1.00 showed a single score indicator reduction from 2.7 Pts for 100\% CEM mortar to 1.1 Pt for GCP with PG.

Table 2. Total $\mathrm{CO}_{2}$ released during the production of $1 \mathrm{~m}^{3}$ of material.

\begin{tabular}{cccccc}
\hline Impact Category & Unit & 100\% CEM Mortar & CEM with MKW & GCP with BG & GCP with PG \\
\hline Total & $\mathrm{kg}$ & 684.6 & 580.3 & 332.2 & 297.0 \\
\hline Fossil $\mathrm{CO}_{2 \text { eq }}$ & $\mathrm{kg}$ & 638.4 & 540.6 & 308.6 & 273.5 \\
Biogenic $\mathrm{CO}_{2}$ eq & $\mathrm{kg}$ & 46.8 & 40.1 & 22.6 & 22.5 \\
$\mathrm{CO}_{2}$ eq from land & $\mathrm{kg}$ & 0.5 & 0.5 & 0.5 & 0.5 \\
transformation & $\mathrm{kg}$ & -1.1 & -1.0 & 0.5 & 0.5 \\
$\mathrm{CO}_{2}$ uptake & $\mathrm{Pt}$ & 2.7 & 2.6 & 1.2 & 1.1 \\
EDP & & & &
\end{tabular}

The calculation results of CML-IA baseline are given in Figure 5. Results indicated that not in all cases do the use of PC as the main binder for mortar give the highest impact on environment. Partial substitution of PC with MKW can give a lower impact, while 25 wt.\% reduction of PC does not give $25 \%$ reduction of relative impact to the environment. The lowest impact was for ternary system-based binder, and the advantage of use of PG was visible as in all cases the environmental benefit was achieved. 


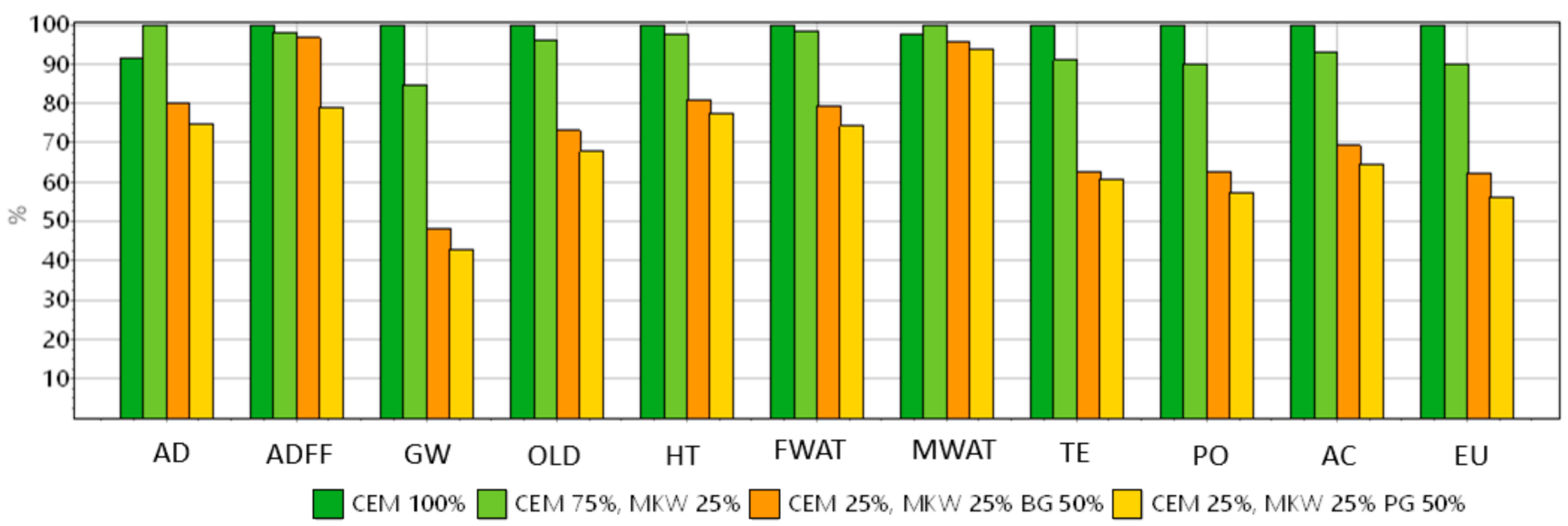

Figure 5. Comparison of different mortar mixtures regarding to the relative impact to the environment. AD—abiotic depletion; AD FF-abiotic depletion (fossil fuels); GW-global warming; OLD—ozone layer depletion; HT_human toxicity; MWAT_fresh water aquatic ecotoxicity; SWAT_marine aquatic ecotoxicity; TE—-terrestrial ecotoxicity; $\mathrm{PO}$ - photochemical oxidation; AC—acidification; EU-eutrophication.

\section{Discussion}

The total energy demand to produce $1 \mathrm{~m}^{3}$ of mortar has been estimated to be $4.2 \mathrm{GJ}$ for mortar with $100 \%$ CEM. Compared to the literature, it was reported that the production of $1 \mathrm{~m}^{3}$ of concrete consumes $2.2 \mathrm{GJ}$ of energy [30]. In the present research obtained, the value was almost two-fold higher, which was associated with a higher PC consumption in the production of mortar. A total of $93.6 \%$ of concrete energy demand was associated with PC, and the amount of PC was lower in the concrete and in the reviewed case it was $460 \mathrm{~kg} / \mathrm{m}^{3}$. A total of $670 \mathrm{~kg} / \mathrm{m}^{3}$ cement consumption in mortar would increase energy demand results, as it was proven in calculations. Obtained mortar strength was also noticeably higher, compared to concrete ( $80 \mathrm{MPa}$ to $40 \mathrm{MPa}$ ). The correlation between PC consumption, properties of material, and energy demand can be seen. Mixture with MKW (CEM 75\%, MKW 25\%) showed only a slightly lower energy demand to produce mortar (only $6 \%$ reduction). This can be explained by a complicated infrastructure of kaolin processing and burning at temperatures from $800-900{ }^{\circ} \mathrm{C}$ (foam glass production takes place at around $860^{\circ} \mathrm{C}$ ). If the allocations would not account for MKW as by-product, the total energy demand would increase. This is one of the main reasons why metakaolin is not used as supplementary cementitious material for concrete or mortar production, as it is high value material. In our case MKW as by-product was much more effective for use in cement mortars. GCP mixture composition with commercial gypsum reduced total energy demand by $18.6 \%$ and with PG-30\%. This was associated with lower energy consumption to produce gypsum binder (both for commercial and PG), while logistics and excavation process was higher for commercial gypsum. Required gypsum drying consumes $0.55 \mathrm{GJ} / \mathrm{t}$ energy and calcination of gypsum gave an additional $0.9-1.0 \mathrm{GJ} / \mathrm{t}$ of energy. In total, it can be estimated about $1.5 \mathrm{GJ} / \mathrm{t}$ of energy was needed to produce gypsum binder [31]. This was significantly lower when compared to PC and metakaolin $(3.6 \mathrm{GJ} / \mathrm{t}$ to $6 \mathrm{GJ} / \mathrm{t}$ for PC and $2.5 \mathrm{GJ} / \mathrm{t}$ for metakaolin). If compared to gypsum plasters, it was calculated that by using secondary gypsum, production energy for plaster needed was $0.72-0.83 \mathrm{GJ} / \mathrm{t}$, while with natural gypsum energy up to $1.31 \mathrm{GJ} / \mathrm{t}$ must be used, and so the difference is roughly $40 \%$ [32].

The total $\mathrm{CO}_{2}$ release was reduced by $15.2 \%$ if partial cement replacement was applied with the supplementary cementitious material MKW. Such a high $\mathrm{CO}_{2}$ reduction can partly be associated with the allocation of MKW origin (as a by-product). For GCP mixtures, where PC was replaced by $75 \%$, the $\mathrm{CO}_{2}$ reduction was reached 51.5 to $56.6 \%$. This was associated with the consumption of MKW (25\%) and also gypsum binder production emissions. 
Nevertheless, the alternative ternary system binder can give significant environmental benefit comparing to traditional mortars.

Comparison of different mixtures regarding to the normalized impact to the environment is given in Table 3. Most impact effected by production of mortar is on marine aquatic ecotoxicity, followed by acidification, abiotic depletion, and global warming. Abiotic depletion and marine aquatic ecotoxicity even increased for mortar with MKW addition. This was previously observed by Zain et al., which concluded that most of the efforts to reduce environmental footprint was dedicated to the release limitations of carbon, while other criteria such as fresh water and marine ecotoxicity, human toxicity, ozone depletion, acidification, and eutrophication was left in second place [33]. GCP mortar was the most promising, as it reduced abiotic depletion normalized score from 12 to $18 \%$ and marine aquatic ecotoxicity from $2-4 \%$, comparing to negative effect of MKW addition $(-9.4 \%$ and $-2.4 \%$ ). Global warming (GWP100a) potential was reduced by MKW incorporation by $15 \%$, while with GCP mortar this number can be increased from $52 \%$ to $57 \%$. In general, the replacement of CEM with $25 \mathrm{wt}$. $\%$ of MKW gives environmental a benefit from $2 \%$ to $15 \%$, while for GCP with commercial gypsum this value is from $2 \%$ to $52 \%$ and with PG-from $4 \%$ to $57 \%$.

Table 3. Normalized impact to the environment for different types of mortars.

\begin{tabular}{cccc}
\hline Impact Category & 100\% CEM Mortar & CEM with MKW & GCP with BG \\
\hline Abiotic depletion & $2.50 \times 10^{-12}$ & $2.73 \times 10^{-12}$ & $2.19 \times 10^{-12}$ \\
Abiotic depletion (fossil fuels) & $8.46 \times 10^{-11}$ & $8.29 \times 10^{-11}$ & $8.18 \times 10^{-11}$ \\
Global warming (GWP100 a) & $1.27 \times 10^{-10}$ & $1.08 \times 10^{-10}$ & $6.16 \times 10^{-11}$ \\
Ozone layer depletion (ODP) & $1.88 \times 10^{-13}$ & $1.81 \times 10^{-13}$ & $1.38 \times 10^{-13}$ \\
Human toxicity & $5.58 \times 10^{-12}$ & $5.45 \times 10^{-12}$ & $5.46 \times 10^{-12}$ \\
Fresh water aquatic ecotox. & $2.03 \times 10^{-12}$ & $2.00 \times 10^{-12}$ & $1.52 \times 10^{-12}$ \\
Marine aquatic ecotoxicity & $1.05 \times 10^{-9}$ & $1.07 \times 10^{-9}$ & $1.61 \times 10^{-12}$ \\
Terrestrial ecotoxicity & $1.27 \times 10^{-11}$ & $1.15 \times 10^{-11}$ & $1.03 \times 10^{-09}$ \\
Photochemical oxidation & $8.72 \times 10^{-12}$ & $7.87 \times 10^{-12}$ & $7.94 \times 10^{-12}$ \\
Acidification & $5.04 \times 10^{-11}$ & $4.69 \times 10^{-11}$ & $5.46 \times 10^{-12}$ \\
Eutrophication & $1.43 \times 10^{-11}$ & $1.29 \times 10^{-11}$ & $3.50 \times 10^{-11}$ \\
\hline
\end{tabular}

\section{Conclusions}

Portland cement (PC) replacement with supplementary cementitious materials (SCMs) at first glance seems effective and an instant solution for the reduction of environmental impact of PC based materials. However, results proved that the total energy demand and $\mathrm{CO}_{2}$ released during production of cement-based materials are not reduced equally to PC reduction and in some scenarios even additional environmental depletion can be initiated. Environmental issues such as harm to abiotic depletion and marine aquatic ecotoxicity can be increased as often SCMs are with limited quantity and availability. The processing can be complicated and can even bring more pollution to environment. One such product proved to be kaolin clay and metakaolin as a pozzolanic material in PC based materials. Metakaolin containing by-product from foam glass production process can be effectively used as SCM and due to the allocations with foam glass granule production, additional environmental benefit can be achieved. The most promising results were achieved with ternary system binder based on gypsum-cement-pozzolan (GCP) system, where PC replacement up to $75 \mathrm{wt} . \%$ was achieved. Even in this scenario, non-linear environmental impact reduction was achieved. Up to $30 \%$ energy demand reduction and $57 \% \mathrm{CO}_{2}$ release reduction was achieved with a GCP binder if secondary gypsum (phosphogypsum) source was used with practically identical performance of mortar material.

Author Contributions: Conceptualization: G.B., A.K. and D.B.; methodology: G.B., A.K. and D.B; software: G.B.; validation: G.B., A.K. and D.B.; formal analysis: G.B.; investigation: G.B.; resources: G.B., A.K. and D.B.; data curation: G.B., A.K. and D.B.; writing-original draft preparation: G.B.; writing-review and editing: G.B., A.K. and D.B.; visualization: G.B.; supervision: A.K. and D.B.; 
project administration: G.B., A.K. and D.B.; funding acquisition: G.B. and D.B. All authors have read and agreed to the published version of the manuscript.

Funding: This research was funded by ERDF within the Activity 1.1.1.2 "Post-doctoral Research Aid" of the Specific Aid Objective (1.1.1 "To increase the research and innovative capacity of scientific institutions of Latvia and the ability to attract external financing, investing in human resources and infrastructure") of the Operational Programme "Growth and Employment" (No. 1.1.1.2/VIAA/1/16/050).

Institutional Review Board Statement: Not applicable.

Informed Consent Statement: Not applicable.

Data Availability Statement: Not applicable.

Conflicts of Interest: The authors declare no conflict of interest.

\section{References}

1. Cai, W.; Wang, C.; Chen, J.; Wang, K.; Zhang, Y.; Lu, X. Comparison of $\mathrm{CO}_{2}$ emission scenarios and mitigation opportunities in China's five sectors in 2020. Energy Policy 2008, 36, 1181-1194. [CrossRef]

2. Uwasu, M.; Hara, K.; Yabar, H. World cement production and environmental implications. Environ. Dev. 2014, 10, 36-47. [CrossRef]

3. Chen, C.; Habert, G.; Bouzidi, Y.; Jullien, A. Environmental impact of cement production: Detail of the different processes and cement plant variability evaluation. J. Clean. Prod. 2010, 18, 478-485. [CrossRef]

4. García-Pérez, J.; López-Abente, G.; Castelló, A.; González-Sánchez, M.; Fernández-Navarro, P. Cancer mortality in towns in the vicinity of installations for the production of cement, lime, plaster, and magnesium oxide. Chemosphere 2015, 128, 103-110. [CrossRef]

5. Moretti, L.; di Mascio, P.; Bellagamba, S. Environmental, Human Health and Socio-Economic Effects of Cement Powders: The Multicriteria Analysis as Decisional Methodology. Int. J. Environ. Res. Public Health 2017, 14, 645. [CrossRef]

6. Valderrama, C.; Granados, R.; Cortina, J.L.; Gasol, C.M.; Guillem, M.; Josa, A. Implementation of best available techniques in cement manufacturing: A life-cycle assessment study. J. Clean. Prod. 2012, 25, 60-67. [CrossRef]

7. Summerbell, D.L.; Barlow, C.Y.; Cullen, J.M. Potential reduction of carbon emissions by performance improvement: A cement industry case study. J. Clean. Prod. 2016, 135, 1327-1339. [CrossRef]

8. Turk, J.; Cotič, Z.; Mladenovič, A.; Šajna, A. Environmental evaluation of green concretes versus conventional concrete by means of LCA. Waste Manag. 2015, 45, 194-205. [CrossRef]

9. Bajare, D.; Bumanis, G.; Upeniece, L. Coal combustion bottom ash as microfiller with pozzolanic properties for traditional concrete. Procedia Eng. 2013, 57, 149-158. [CrossRef]

10. Bumanis, G.; Vitola, L.; Stipniece, L.; Locs, J.; Korjakins, A.; Bajare, D. Evaluation of Industrial by-products as pozzolans: A road map for use in concrete production. Case Stud. Constr. Mater. 2020, 13, e00424. [CrossRef]

11. Moropoulou, A.; Koroneos, C.; Karoglou, M.; Aggelakopoulou, E.; Bakolas, A.; Dompros, A. Life cycle analysis of mortars and its environmental impact. MRS Online Proc. Libr. (OPL) 2005, 895, 0895-G06-02. [CrossRef]

12. Consoli, F.; Allen, D.; Boustead, I.; Fava, J.; Franklin, W.; Jensen, A.A.; de Oude, N.; Parrish, R.; Perriman, R.; Postethwaite, D.; et al Guidelines for Life-Cycle Assessment: A Code of Practice; Report from the Workshop of the Society of Environmental Toxicology and Chemistry (SETAC), Held at Sesimbra (Portugal): 31 March-3 April 1993; SETEC: Brussels, Belgium, 1993.

13. Baumann, H. Decision Making and Life Cycle Assessment. Licentiate Thesis, Chalmers University of Technology, Göteborg, Sweden, 1995.

14. Klimesch, D.S.; Ray, A. Use of the second-derivative differential thermal curve in the evaluation of cement-quartz pastes with metakaolin addition autoclaved at $180^{\circ} \mathrm{C}$. Thermochim. Acta 1997, 307, 167-176. [CrossRef]

15. Guinée, J.B. Handbook on Life Cycle Assessment: Operational Guide to the ISO Standards; Kluwer Academic Publishers: Dordreecht, The Netherlands, 2002.

16. Habert, G.; de Lacaillerie, J.B.; Roussel, N. An environmental evaluation of geopolymer based concrete production: Reviewing current research trends. J. Clean. Prod. 2011, 19, 1229-1238. [CrossRef]

17. Environmental Product Declaration Operator. An Industry Average Cradle-to-Gate Life Cycle Assessment of $\frac{1}{2}$ “Lightweight and 5/8" Type X Conventional Gypsum Board for the USA and Canadian Markets EPD Project Report, 2020. Gypsum Association. Declaration No.: EPD 10270. Industry Average EPD for 5/8" Type X Conventional Gypsum Board. 2020. Available online: https://www.usg.com/content/dam/USG_Marketing_Communications/united_states/product_promotional_ materials / finished_assets/2020-type-x-wallboard-epd-en.pdf (accessed on 10 November 2021).

18. Suárez, S.; Roca, X.; Gasso, S. Product-specific life cycle assessment of recycled gypsum as a replacement for natural gypsum in ordinary Portland cement: Application to the Spanish context. J. Clean. Prod. 2016, 117, 150-159. [CrossRef]

19. Silgado, S.S.; Valdiviezo, L.J.C.; Domingo, S.G.; Roca, X. Multi-criteria decision analysis to assess the environmental and economic performance of using recycled gypsum cement and recycled aggregate to produce concrete: The case of Catalonia (Spain). Resour. Conserv. Recycl. 2018, 133, 120-131. [CrossRef] 
20. Camarini, G.; dos Santos Lima, K.D.; Pinheiro, S.M.M. Investigation on gypsum plaster waste recycling: An eco-friendly material. Green Mater. 2015, 3, 104-112. [CrossRef]

21. Rivero, A.J.; Sathre, R.; Navarro, J.G. Life cycle energy and material flow implications of gypsum plasterboard recycling in the European Union. Resour. Conserv. Recycl. 2016, 108, 171-181. [CrossRef]

22. Pedreño-Rojas, M.A.; Fořt, J.; Černý, R.; Rubio-de-Hita, P. Life cycle assessment of natural and recycled gypsum production in the Spanish context. J. Clean. Prod. 2020, 253, 120056. [CrossRef]

23. Life Cycle Management of Phosphogypsum Stacks-International Fertiliser Society. Available online: https://fertiliser-society org/store/life-cycle-management-of-phosphogypsum-stacks / (accessed on 27 August 2020).

24. Nizevičienè, D.; Vaičiukynienè, D.; Michalik, B.; Bonczyk, M.; Vaitkevičius, V.; Jusas, V. The treatment of phosphogypsum with zeolite to use it in binding material. Constr. Build. Mater. 2018, 180, 134-142. [CrossRef]

25. Bumanis, G.; Zorica, J.; Bajare, D. Properties of foamed lightweight high-performance phosphogypsum-based ternary system binder. Appl. Sci. 2020, 10, 6222. [CrossRef]

26. Laurent, A.; Clavreul, J.; Bernstad, A.; Bakas, I.; Niero, M.; Gentil, E.; Christensen, T.H.; Hauschild, M.Z. Review of LCA studies of solid waste management systems-Part II: Methodological guidance for a better practice. Waste Manag. 2014, 34, 589-606. [CrossRef] [PubMed]

27. Kulczycka, J.; Kowalski, Z.; Smol, M.; Wirth, H. Evaluation of the recovery of Rare Earth Elements (REE) from phosphogypsum waste-Case study of the WIZÓW Chemical Plant (Poland). J. Clean. Prod. 2016, 113, 345-354. [CrossRef]

28. European Commission-Joint Research Centre. European Commission-Joint Research Centre - Institute for Environment and Sustainability: International Reference Life Cycle Data System (ILCD) Handbook-General guide for Life Cycle AssessmentDetailed guidance. First edition March 2010. EUR 24708 EN. Luxembourg. Publications Office of the European Union; 2010. Page 43. 2010. Available online: https:/ / eplca.jrc.ec.europa.eu/uploads/ILCD-Handbook-General-guide-for-LCA-DETAILEDGUIDANCE-12March2010-ISBN-fin-v1.0-EN.pdf (accessed on 10 November 2021).

29. Finnveden, G.; Hauschild, M.Z.; Ekvall, T.; Guinée, J.; Heijungs, R.; Hellweg, S.; Koehler, A.; Pennington, D.; Suh, S. Recent developments in Life Cycle Assessment. J. Environ. Manag. 2009, 91, 1-21. [CrossRef] [PubMed]

30. Alsalman, A.; Assi, L.N.; Kareem, R.S.; Carter, K.; Ziehl, P. Energy and $\mathrm{CO}_{2}$ emission assessments of alkali-activated concrete and Ordinary Portland Cement concrete: A comparative analysis of different grades of concrete. Clean. Environ. Syst. 2021, $3,100047$. [CrossRef]

31. Venta, G.J. Life Cycle Analysis of Gypsum Board and Associated Finishing Products; Athena Sustainable Materials Institute: Ottawa, ON, Canada, 1997.

32. Baran, E.; Czernik, S.; Hynowski, M.; Michałowski, B.; Piasecki, M.; Tomaszewska, J.; Michalak, J. Quantifying environmental burdens of plasters based on natural vs. Flue gas desulfurization (FGD) gypsum. Sustainability 2021, 13, 4298. [CrossRef]

33. Zain, H.; Al Bakri Abdullah, M.M.; Hussin, K.; Ariffin, N.; Bayuaji, R. Review on Various Types of Geopolymer Materials with the Environmental Impact Assessment. MATEC Web Conf. 2017, 97, 01021. [CrossRef] 